\title{
Role of Notary in Abroad and Indonesia
}

\author{
Haingo Rabanirajona *) \\ *) Universite Libre De Brucelles, Belgium, Email: hrabarij@ulb.ac.be
}

\begin{abstract}
One of the important professions in society is notary. This profession is a special profession because it is a public official in carrying out its duties which is bound by juridical norms and professional code of ethics. The notary code of ethics becomes a moral principle determined by the Indonesian Notary Association (INI) which is the basis for organizing or regulating the notary professional code of ethics in relation to many parties, which of course must be obeyed or obeyed by every member who is bound or binds himself/herself in the association (organization) that. The consequences as a member of this profession must be understood by a notary, because sourced from here, the dignity of the profession can be maintained. The position of the Notary which is urgent in human life makes the process of someone who wants to become an expert notary public important. Therefore, in notarial education, notary ethics should also be considered. So in this case it is emphasized that a professional education without education on responsibility and professional ethics is not complete. In the field of law, technical skills that ignore aspects relating to the responsibilities entrusted to him and his profession in general, as well as ethical values and measurements that must serve as guidelines in carrying out his profession.
\end{abstract}

Keywords: Duties; Authority; Obligations; Position; Professionalism.

\section{INTRODUCTION}

Notary is a public official who is authorized to make authentic deeds as long as the making of certain authentic deeds is not specific to other public officials. The making of authentic deeds is required by laws and regulations in order to create legal certainty, order and protection. In addition to authentic deeds made by or before a notary public, not only because they are required by laws and regulations, but also because the interested parties want them to ensure the rights and obligations of the parties for certainty, order and legal protection for the parties concerned as well as for society as a whole.

The task of the notary is to arrange in writing and authentically the legal relationship between the parties who have entered into a consensus agreement using the services of a notary, which in essence provides legal certainty for the agreement that has been signed. Here it is clear that a notary is a position free from the influence of any pressure, but has strong legal certainty, therefore in every grosse a certain deed always includes the sentence "For Justice Based on the Almighty God". This has a consequence that the notary deed has executorial power. 
Notaries in their profession act as public servants as officials appointed by the government. In his service, the Notary is bound by the Position Regulations and the professional code of ethics as a notary. The position of the notary that is urgent in human life makes the process of someone who wants to become an expert notary public important. Therefore, in notarial education, notary ethics should also be considered. So in this case it is emphasized that a professional education without education on responsibility and professional ethics is not complete. In the field of law, technical skills that ignore the aspects related to the responsibility entrusted to them and the profession in general, as well as ethical values and standards that must serve as guidelines in carrying out their profession, will only become skilled craftsmen in the field of law and their profession. ${ }^{1}$ The notary profession is a general official in carrying out his duties bound by laws and professional code of ethics ${ }^{2}$.

The notary code $^{3}$ of ethics is a moral code determined by the association of the Indonesian Notary Public Association (INI) based on the congress decision of the association and/or which is determined and regulated in the laws and regulations governing the notary professional code of ethics, it must be obeyed by every member who is bound by the association. Article 83 paragraph (1) of Act No 30 of 2004, concerning Noratis Position states that, "Notary organizations determine and enforce notary code of ethics." Then in the provisions of Article 13 paragraph (1) of the Articles of Association of the Indonesian Notary Association, which was established based on the Extraordinary Congress of the Indonesian Notary Association in Bandung on January 28, 2005, states: "To maintain the honor and dignity of the office of notary public, the association has a notary code of ethics established by the congress and is a moral principle that must be obeyed by every member of the association." Notaries in their profession who provide services to the community should act according to the applicable rules.

Notaries have an obligation to ensure the correctness of the deeds they make, therefore notaries must be more sensitive, honest and fair in making a deed. As is well known, some of the duties of a Notary, one of which is to arrange in writing and authentically the legal relationships between the parties who agree to request the Notary's services. The association has a notary code of ethics established by the congress and is a moral principle that must be obeyed by every member of the association. Notaries in their profession who provide services to the community should act according to the applicable rules. Notaries have an obligation to ensure the correctness of the deeds they make, therefore notaries must be more sensitive, honest and fair in making a deed. As is well known, some of the duties of a Notary, one of which is to arrange in writing and authentically the legal relationships between the parties who agree to request the Notary's services. The association has a notary code

1 Darmodiharjo, Darji \& Shidarta. (2004). Pokok-pokok Filsafat Hukum, Apa dan BagaimanaFilsafat Hukum Indonesia. Jakarta: PT Gramedia Pustaka Utama, p. 265

2 Deen, Thaufiq., Ong Argo Victoria \& Sumain. (2018). Public Notary Services In Malaysia. JURNAL AKTA: Vol. 5, No. 4, 1017-1026. Retrieved from http://jurnal.unissula.ac.id/index.php/akta/article/view/4135

3 Ferdiyanti, M. Indah Verena., Purnawan, Amin., \& Soegiyanto. (2019). Setting the Effectiveness of Law Position and Code Notary to the Quality of Performance. JURNAL AKTA: Vol. 6, No. 4, 797-804. Retrieved from http://jurnal.unissula.ac.id/index.php/akta/article/view/7887 
of ethics established by the congress and is a moral principle that must be obeyed by every member of the association.

Notaries in their profession who provide services to the community should act according to the applicable rules. Notaries have an obligation to ensure the correctness of the deeds they make, therefore notaries must be more sensitive, honest and fair in making a deed. As is well known, some of the duties of a Notary, one of which is to arrange in writing and authentically the legal relationships between the parties who agree to request the Notary's services. therefore, a Notary must be more sensitive, honest and fair in making a deed. As is well known, some of the duties of a Notary, one of which is to arrange in writing and authentically the legal relationships between the parties who agree to request the Notary's services.

Therefore, a Notary must be more sensitive, honest and fair in making a deed. As is well known, some of the duties of a Notary, one of which is to arrange in writing and authentically the legal relations between the parties who agree to request the Notary's services. ${ }^{4}$ Notary as a General Officer, according to Article 1 point 1 of Act No 30 of 2004 jo. Act No 2 of 2014 states that the main task of a notary is to make authentic deeds. The authentic deed according to Article 1868 of the Civil Code (hereinafter referred to as the Civil Code) is a deed which is in the form determined by law, made by or in front of public officials who are in power for it at the place where the deed it was made. This implies that the notary because of the law is given the authority to create absolute means of proof, in the sense that what is stated in the authentic deed is in essence deemed true. ${ }^{5}$ Notaries are also required to have high moral values, because with high moral values, the Notary will not abuse the authority he has, so that the Notary will be able to maintain his dignity as a public official who provides services in accordance with applicable rules and does not damage the image of the Notary itself.

As the hope of all of us or the nation, so that every Notary has sufficiently broad and deep knowledge and skills so that it is the mainstay of the community in designing, compiling and making various authentic deeds, so that the language structure, juridical techniques are neat, good and correct, because besides this expertise is needed also honesty or sincerity and an objective nature or outlook. As we know, notary institutions have been known by the public and are needed in making authentic written evidence of a legal act committed by the community. The need for a notary institution in daily legal practice cannot be separated from the increasing level of the economy and public legal awareness. The form of this notarial institution can be divided into two main groups, namely:

a. Notary Fonctionnel, in which government authorities are delegated (gedelegeerd) and thus alleged to have the correctness of the contents, have formal evidence strength and have the power/power of execution. In countries that adhere to this kind of fonctionnel notary there is a strict separation

\footnotetext{
${ }^{4}$ Supriadi. (2008). Etika Dan Tanggung Jawab Profesi Hukum Di Indonesia. Jakarta: Sinar Grafika, p. 50

${ }^{5}$ Notodisoerjo, R. Soegondo. (1993). Hukum Notariat di Indonesia Suatu Penjelasan. Jakarta: PT. Raja Grafindo Persada, p. 8
} 
between wettelijk and niet wettelijke werkzaamheden, namely jobs which are based on law/law and those not/not in the notary;

b. Notarial Professionnel, in this group, even though the government regulates its organization, the notarial deeds do not have special consequences regarding the truth, strength of evidence, as well as the power of its execution. Izenis's theory is based on the idea that the notary is part of or closely related to the judiciary/court (rechtelijke macht), as is the case in France and the Netherlands.

\section{METHODS}

The method used in this study is a qualitative method. Qualitative research methods are research used to examine the conditions of natural objects, where the researcher is the key instrument.

\section{RESULTS AND DISCUSSION}

\subsection{History of Notary}

According to the history of the Notary Public Notary originated from the era in the IIIII century, at that time the notary functioned as a speech recorder called scribae, tebellius, or notaries which is one of the existing legal professions. ${ }^{6}$ In the V-VI centuries the term notarius was given to the personal writer (secretary) of the king or emperor and to officials from the court who carried out administrative work. Officials called notaries are officials who carry out their duties only for the government and do not serve the public or the general public. Related to the task of serving the public, it is called tubelliones, whose function is somewhat similar to that of a notary at this time. It's just that it does not have the character of amblitjke, the nature of the state office so that the letters it produces do not have an authentic or official character. Notaries who enter Indonesia, come from countries in Europe and especially from the Netherlands.

The Netherlands as a country that colonized the Indonesian nation, which regulates the regulations regarding the notary. In 1860 the Dutch changed the old regulations with a Notary Position Regulation known as Reglement op Het Notary Ambt in Indonesia (Stb. 1860; 3), effective July 1,1860 . Which until now there have been several expert changes. Lastly changed to UUJN-P. Notarial institutions in Indonesia originate from the Netherlands and have been known since the Dutch colonized Indonesia. Initially, this notarial institution was primarily intended for the Dutch and other European groups as well as the Bumi Putera group who, due to law or because of some provisions, were declared to be subject to the law applicable to European groups in the field of civil law or to submit to the Burgelijk Wetboek (BW) or generally referred to as the Civil Code. Notarial institutions are increasingly recognized by the public and are needed in making authentic written evidence of a legal act committed by the community. The need for a notary institution in day-to-day legal practice cannot be separated from the increasing level of the economy and public legal awareness.

\footnotetext{
${ }^{6}$ Anshori, Abdul Ghofur. (2010). Lembaga Kenotariatan Indonesia Persefektif Hukum dan Etika. Yogyakarta: UII Press, p. 8.
} 
The strength of an authentic deed made by a notary has very strong legal force considering that authentic deeds are perfect evidence. So it is not uncommon for various laws and regulations to require certain legal actions to be made in authentic deeds, such as the establishment of limited liability companies, cooperatives, fiduciary guarantee deeds and so on. Besides these deeds are made at the request of the parties. In the current era of globalization, notarial institutions play an important role in people's lives, ${ }^{7}$ With the development of the economic and socio-cultural life of the community, the need for a Notary is increasingly felt necessary in the life of the community, therefore the notary's position is considered appropriate as a functionary in society, an official where someone can get reliable advice, an official who can make a document strong so that can be used as evidence in the legal process.

Notaries and their act products can be interpreted as state efforts to create legal certainty and protection for members of the public. Considering that in the private/civil jurisdiction, the state places a Notary as a public official who has the authority to make authentic deeds, for the purposes of proof/evidence. Written evidence can be in the form of writing under hand and in the form of an authentic deed, authentic deeds as the strongest and fulfilled evidence have an important role in every legal relationship in people's lives. In various business relations, activities in banking, land affairs, social activities, etc., the need for written proof in the form of authentic deeds is increasing in line with the growing demands for legal certainty in various economic and social relations, at the national, regional, and global.

\subsection{Definition of Notary}

Notary is a public official who is appointed by the government to assist in carrying out state duties in providing legal services to the public in order to achieve legal certainty as an official deed maker in civil matters. The definition of a notary in Article 1 of Act No 2 of 2014 concerning the Position of Notary, which states that "Notary is a public official who is authorized to make authentic deeds and has other powers as referred to in this Law or based on other laws". Whereas in order to make an authentic deed, a person must have a position as a "public official". So in the notaries above, there are important things implied, namely the provisions in the beginning of the article,

Definition of a notary in the opinion of scholars:

a. R. Soegondo Notodisoerjo, "Notaries are public officials of openbare ambtenaren, because they are closely related to the main authority or duties and obligations, namely to make authentic deeds".

b. According to Tan Thong Kie, "Notary is a functionary in society, until now the position of a Notary is still respected. A notary is usually considered as a handshake where someone can get reliable advice. Everything that is written

\footnotetext{
7 Kie, Tan Thong. (2000). Buku 1 Studi Notariat dan Serba Serbi Praktek Notaris, Jakarta: PT. Ichtiar Baru Van Hoeve, p. 449.

8 Notodisoerjono, R. Soegondo. (1993). Hukum Notariat di Indonesia Suatu Penjelasan, Jakarta: Raja Grafinso Persada, p. 8.
} 
and determined (constants) is true, he is a strong document maker in a legal process". ${ }^{9}$

c. According to Colenbrunder in GHS Lumban Tobing, "Notary is an authorized official at the request of those who ask him to record everything experienced in a deed, thus he makes an official report and what is discussed in the shareholder meeting, which is attended at the request of the company management or regarding the auction nets which are carried out at the request of the seller, thus he witnesses (comtuleert) in the deed about the condition of an item pointed to him by the client ". ${ }^{10}$

According to the legal system there are 2 (two) notary schools in the world, namely Latin Notaries and Anglo Saxon Notaries. A Latin notary is essentially a private legal professional, such as a lawyer, who also prepares documents on behalf of the parties to ensure that the documents comply with applicable laws and regulations. "The Latin Notary is an legal professional like an attorney who also prepares documents on behalf of both side in a transaction and ensures that these documents meet the legal requirements of the appropirate jurisdiction". ${ }^{11}$ Meanwhile, the Anglo Saxon Notary is not a professional legal official but is chosen from among the members of the community who have high integrity and morals. "An American Notary public is a" citizen of high moral character and integrity "who is legally empowered to witness and certify the validity of documents and take attestations and depositions. He is not a person who practices law ".

Notaries in Latin are adopted by countries that adhere to the Civil Law System, while Anglo Saxon Notaries are adopted by countries that adhere to the Common Law System. Civil Law refers to Roman (Northern Italian) law which put everything into legislation. Meanwhile, Case Law originated in England and emerged in the Middle Ages where the law was developed from a general judgment. Jurisprudence is an essential part of the Case Law system. In Anglo Saxon (common law), notary public (Notary) only becomes legislators from the signature of those who make the agreement, while the agreement itself is made by the Lawyer. At that time, notaries needed in-depth legal knowledge because they were not only obliged to justify the signature but also compose words and provide input if needed before the deed was drawn up. Related to this, the Notary Public can make an important contribution to the development of the national legal and notarial institutions. ${ }^{12}$

Countries that adhere to the Latin Notary system include countries from the European continent (Italy, France, Spain, the Netherlands, Belgium, Portugal), except for some Scandinavian countries, Asian countries, Africa, Latin America, Quebec, and the State of Louisina in the United States. Meanwhile, countries that adhere to Anglo Saxon notaries are the United States, except for Louisiana, England, and some countries in Scandinavia, as well as British colonies in Asia and Africa such as Singapore, Malaysia,

\footnotetext{
${ }^{9}$ Kie, Tan Thong, (2007). Studi Notariat beberapa Mata Pelajaran dan Serba Serbi Praktek Notari. Jakarta: Pt. Ichtiar Baru Van Hoeve, p. 157.

${ }^{10}$ Tobing, G.H.S. Lumban. (1999). Peraturan Jabatan Notaris. Jakarta: Erlangga, p. 33.

${ }^{11}$ Thaw, Deborah M. (2000). The Notary Public and its Impact in 21st Century, A Persentation at the NACO/NACRC Annual Conference. p. 2.

12 Indonesian Notary Association Central Board, Ibid.
} 
the Philippines, and Australia. ${ }^{13}$ Indonesia adheres to the Latin Notary School, not Anglo Saxon Notary.

Notaries in Indonesia provide legal advice to parties, as long as it does not conflict with applicable laws, order, and morals. Unlike notaries in the United States who are only responsible for the accuracy and legality of the contents of the deed agreement. Therefore, the deed produced by the Latin Notary is very much taken into account by the court because it is authentic evidence, on the other hand the deed produced by the Anglo Saxon Notary is not considered as evidence by the court. Anglo Saxon notaries carry out simple paralegal tasks, such as validating signatures or compiling a power of attorney.

This simple understanding must be known to Indonesian notaries and stakeholders, such as police, prosecutors, judges, ministers of justice, business people, and the general public. Because if not, there will be confusion over "rules of the game" which have the potential to reduce the quality of the Civil Law system in Indonesia. It is common practice, Indonesia has adopted many Western (United States) thoughts and cultures, whereas the United States has adopted an Anglo Saxon system that is different from the Latin Notary School. The concepts and practices in the Latin Notary System cannot be mixed with the concepts and practices of the Anglo-Saxon Notary System which is philosophically very different. In a country that adheres to civil law, a 'code' (law) is a collection of clauses and general legal principles that are authoritative, comprehensive and systematic, which are contained in books or sections that are structured logically in accordance with related laws. Civil law regulations are the main source of law, to which all other sources of law are subordinated.

According to Hartanti Sulihandari and Nisya Rifani, the differences between Civil Law and Common Law Notaries are as follows:

\section{a. Civil Law Notary}

In civil law countries, judges only act as those who apply the law, not as the party who determines the law. In this system, the existence of laws and regulations is very important, rather than judges' decisions. The law that is made is a tool to regulate the life of the community, even the relationships between individuals are also regulated in it. ${ }^{14}$ Notaries in the civil law system are the same as judges. Notary is only the party who applies the rules. The government appoints Notaries as people who become "servants" of the community. As a party appointed by the state, a Notary can be categorized as a state official. Having status as a state official means that a notary is a representative of the state. The State delegates the authority to the Notary to record and determine as well as raise legal awareness to the public, especially regarding the legality of the agreement or cooperation document. A notary made by a notary is a perfect authentic deed so that it can be used as a valid evidence in court. By holding an authentic deed will give legal power so that if sued by another party, the evidence in the form of a deed has perfect evidentiary power.

\footnotetext{
13 Ibid. p. 43-43.

14 Sulihandari, Hartanti \& Nisya Rafiani. (2013). Prinsip-Prinsip Dasar Profesi Notaris. Jakarta: Dunia Cerdas, p. 11.
} 


\section{b. Common Law Notary}

In the common law system, the rule of law is set by a judge. Judges are not only law enforcers, but also decide and stipulate legal regulations referring to the provisions of the previous judge. This shows that in the beginning the legal system was not something that was a priority, but rather the decisions of judges who took priority positions, the law only acted as a solution to prevent problems in court. Laws do not exist to regulate individual-individual relationships. ${ }^{15}$ The position of a notary in the common law system is different from a notary in civil law, that is, a Notary is not a state official. They are not appointed by the state, but they are private notaries who work without any government ties. They work only as legalizers of the agreement made by the parties. The agreement making does not involve a notary, but is drawn up together with a lawyer/lawyer. So that the resulting documents are not strong enough to be used as evidence in court.

\subsection{Notary Position}

Position is a legal subject (persoon), namely supporters of rights and obligations. By statute law power is not given to officials (people) but given to positions (work environment). As a legal subject, namely a legal entity, the position can guarantee continuity of rights and obligations. Officials (who occupy positions) always keep changing, while positions continue. ${ }^{16}$ The position of a Notary is held or its presence is desired by legal regulations with the intention of helping and serving people who need authentic written evidence regarding conditions, events or legal actions. Notary position is an institution created by the State. ${ }^{17}$

The position of a notary is actually an important part of the Indonesian state which adheres to the principles of a rule of law (Article 1 paragraph (3) of the 1945 Constitution of the Republic of Indonesia). With this principle, the State guarantees legal certainty, order and legal protection, through evidence that clearly determines the rights and obligations of a person as a legal subject in society. One of the guarantees for legal certainty that provides legal protection is the strongest and most fulfilling evidence, and has an important role in the form of an "authentic deed". Position is a field of work or task that is deliberately made by legal regulations for certain purposes and functions and is sustainable as a permanent work environment. Position is a legal subject, namely a supporter of rights and obligations. In order for a position to run, the position is carried by another legal subject, namely person. The person appointed to carry out the Position is called the Officer. A position without an official, then the position cannot run. ${ }^{18}$

Notary as a public official who is appointed by the government to provide services to the community and assist community legal issues based on the Law on Notary Position. General Officer is a position that is carried or given to those who are authorized by

\footnotetext{
15 Ibid. p. 12.

${ }^{16}$ Adjie, Habib. (2009). Sekilas Dunia Notaris \& PPAT Indonesia (Kumpulan Tulisan), Bandung: CV. Badar Maju, p. 3.

${ }_{17}$ Manan, Bagir. (2004). Hukum Positif Indonesia. Yogyakarta: UII Press, p. 15

${ }^{18} \mathrm{http}: / /$ www.indonesianotarycommunity.com/k Character-yuridis-jabat-notaris/, accessed on January 5, 2020 12:56
} 
legal rules in making authentic deeds. Notary as a General Officer is given the authority to make an authentic deed. Therefore, a Notary is definitely a General Officer. ${ }^{19}$

\subsection{Duties, Authorities and Obligations of a Notary Public Duty;}

The duties of a notary are stipulated in Article 1 point (1) UUJN-P that notaries are public officials who have the authority to make authentic deeds and other powers in this law or other laws. From the above explanation, what is the basis of the authority of a Notary is not only regulated in UUJN/UUJN-P but also regulated in other laws and regulations.

According to Setiawan, the essence of the notary's duty is to regulate in writing and authentically the legal relationship between parties who benefit from requesting the services of a notary which is basically the same as the duty of a judge who provides justice. In addition to making an authentic deed, a Notary is also tasked with providing legal counseling for clients who come to him or want to consult, therefore Notaries are required to know the UUJN/UUJN-P and other statutory regulations. A Notary is appointed through the requirements stipulated in Article 3 UUJN-P which stipulates that:

The requirements to be appointed as Notary as referred to in Article 2 are:

a. Indonesian citizens;

b. Fear god almighty;

c. Be at least 27 (twenty seven) years old;

d. Physically and mentally healthy as stated by a health certificate from a doctor and psychiatrist;

e. Has a law degree and graduated from the bachelor's degree in notary;

f. Has undergone an internship or has actually worked as a notary employee for a period of at least 24 (twenty four) consecutive months at the notary's office on his own initiative or on the recommendation of the notary organization after passing the strata two notary;

g. Not having the status of a civil servant, state official, advocate, or not currently holding another position which is prohibited by law to be concurrently held as a notary; and

h. Has never been sentenced to imprisonment based on a court decision that has obtained permanent legal force for committing a criminal act which is punishable by imprisonment of 5 (five) years or more.

\footnotetext{
${ }^{19}$ http://www.jimlyschool.com/read/anal/384/notaris-openbare-amtbtenaren-syafran-sofyan/, accessed on January 5, 2020 14:21.
} 
The position of a Notary based on Article 18 UUJN-P, namely:

a. Notary has a domicile in a regency or city.

b. A notary has an office area covering the entire province of his/her place of domicile. Therefore, the working area of a Notary is very wide, even though his/her domicile is determined in a district or city, so that, for example, a Notary who is domiciled in Singaraja Regency can make a client deed in Tabanan Regency, because it is a province, namely Bali. This is enforced to prevent concentration in only one notary. Notary who is also a Land Deed Making Official (PPAT), his FIRST must follow the domicile of a Notary based on Article 19 number (2) UUJN-P. ${ }^{20}$

\section{Authority;}

The authority of a notary is stipulated in Article 1 UUJN-P, namely to make authentic deeds and specifically in Article 15 UUJN-P related to the authority to make deeds regarding all actions, agreements, and stipulations required in statutory regulations, ensuring certainty of date of manufacture, storage, giving grosse, copies and excerpts of deeds as long as they are not assigned or excluded to other officials or other people as stipulated by law. The difference between an act and a legal event is. Legal events are social events that bring legal consequences regulated by law. Legal events are divided into legal events due to the actions of legal subjects (wills grant), and legal events that are not acts of legal subjects (birth, death, expiration). Legal action is any action whose result is regulated by law, because the result can be considered as the will of the person who commits the act. Divided into actions of legal subjects which are one-sided legal actions (establishment of PT) and two or more sides (buying and selling, leasing), actions of legal subjects that are not illegal acts (Zaakwarneming and Onrechtmatigedaad). ${ }^{21}$

Other than the above description, the Notary is also authorized to carry out legalization, warmerking, make copies of the original letter under hand, validate the suitability of the photocopy with the original letter, provide legal education in connection with the request for deeds

Notary's authority covers four things, namely:

a. The notary must be authorized to the extent that the deed must be drawn up (as long as it is not excluded from other parties or officials);

b. The notary must be authorized as long as there are persons for whom the deed was drawn up;

${ }^{20}$ Widyawati, \& Handoko, Widhi. (2018). The Notary Role/PPAT in Improving Legal Awareness Society to Perform Registration Rights to Land Based on Government Regulation No. 24 of 1997 on Land Registration. JURNAL AKTA: Vol. 5, No. 4, 975-980. Retrieved from http://jurnal.unissula.ac.id/index.php/akta/article/view/4127

${ }^{21}$ R. Soeroso. (2016). Pengantar I/mu Hukum. Print. 17. Jakarta: Sinar Grafika, p. 252-255. 
c. The notary must be authorized as far as the place where the deed was made;

d. The notary must be authorized as long as the deed is drawn up. ${ }^{22}$

\section{Obligations;}

In carrying out his position, a notary is regulated in Article 16 UUJN-P, so he must:

a. In carrying out his/her office, a Notary must:

1) acting trustworthy, honest, thorough, independent, impartial, and safeguarding the interests of parties involved in legal actions;

2) make Deeds in the form of Minuta Deeds and keep them as part of the Notary protocol;

3) attaching letters and documents as well as the tappers' fingerprints on the Minuta Deed;

4) issue Grosse Deed, Copy of Deed, or Quotation of Deed based on Minuta Deed;

5) provide services in accordance with the provisions of this law, unless there is a reason to refuse it;

6) keep everything concerning the Deed he has made and all information obtained for the making of the Deed in accordance with the oath/promise of office, unless the law stipulates otherwise;

7) Binding the Deeds that he makes in 1 (one) month into a book containing no more than 50 (fifty) Deeds, and if the number of Deeds cannot be contained in one book, the Deeds can be bound into more than one book, and record the Minuta Deed;

8) make a list of the deed of protest against not being paid or not receipt of securities;

9) make a list of deeds relating to wills according to the time line of making deeds every month;

10) submitting the list of Deeds as referred to in letter $i$ or the nil list relating to wills to the center of testament at the ministry that administers government affairs in the field of law within 5 (five) days in the first week of each following month;

11) record in the reportorium the date of delivery of the testament at the end of each month;

12) has a stamp or seal bearing the symbol of the Republic of Indonesia and in the space surrounding it is written the name, position and domicile of the person concerned;

13) read out the Deed in front of the audience in the presence of at least 2 (two) witnesses, or 4 (four) special witnesses for the making of the will under hand, and signed on the spot by the tappers, witnesses and notaries; and

14) accepting internship for prospective Notaries

22 Op.cit, p. 130-134. 
b. The obligation to keep the Minuta Deed as referred to in number (1) letter $b$ does not apply, in the event that the Notary issues the Deed in original.

c. Deed in original as referred to in number (2) includes:

1) Deed of payment of rent, interest and pension;

2) Cash payment offer deed;

3) Deed of protest against non-payment or non-receipt of securities;

4) Power of attorney;

5) Certificate of ownership;

6) Other deeds in accordance with the provisions of laws and regulations.

In carrying out his office, a notary is obliged to be impartial, in this case, to act fairly in protecting the interests of the parties. The notary is also obliged to act carefully, to be careful means being thorough and careful in making deeds.

Rejecting a deed can be done by a notary based on Article 16 number (1) letter e which is done for legal reasons. In the explanation of Article 16 number (1) letter e, the reason for rejecting it is the reason that causes a Notary to take sides, for example, such as family or blood relations or a marriage with the Notary himself or with his own husband or wife, one party is unable to act for does an act, or other thing that is not allowed by law, such as the sale and purchase of goods that are prohibited from being traded.

According to Soegondo Notodisoerjo in practice there are reasons others so that the notary refuses to provide his services, including:

a. If the notary is sick so he cannot provide his services, he will be unable to because of his physicality.

b. If the notary is absent because he is on leave, he is due to valid reasons.

c. If the notary, because of his busy work, cannot serve other people.

d. If the documents needed to make a deed are not submitted to the notary.

e. If the investigator or intrumentair witness presented by the applicant is not recognized by the notary or cannot be introduced to him.

f. If the interested party does not want to pay the obligatory stamp duty.

g. If because of the provision of such services, the notary violates his oath or commits an unlawful act.

h. If the parties want that the Notary makes the deed in a language that is not mastered by him, or if the people facing him speak in an unclear language, so that the Notary does not understand what they want.

The authority and obligations of a notary have been previously described so that there are rights that can be received by the notary, which has previously been explained that the notary receives a salary which is called an honorarium. Economic value is determined in Article 36 UUJN, there are 3 (three) criteria, namely: 
1) Value up to IDR $100,000,000.00$ (one hundred million rupiah), Notary receives an honorarium of at most $2.5 \%$.

2) The value is between IDR $100,000,000.00$ (one hundred million rupiah) to IDR $1,000,000,000.00$ (one billion rupiah), the Notary shall receive a maximum honorarium of $1.5 \%$.

3) A value of more than IDR $1,000,000,000.00$ (one billion rupiah), the Notary will receive an honorarium based on the Notary's agreement with the parties, but it does not exceed $1 \%$ of the object for which the deed is made. Honorarium plus sociological value based on the social function of the deed, a maximum of five million rupiah.

\subsection{Notary Code of Ethics}

In carrying out his/her office, in addition to referring to the law, a notary must also act in accordance with the code of professional ethics. A code of ethics for the notary profession is very necessary in order to maintain the quality of legal services provided to the public. The Indonesian Notary Association (INI) as a professional organization whose validity is recognized in accordance with Act No 30 of 2004 concerning the Position of Notary Public Article 83 paragraph (1) states that, "Notary organizations determine and enforce the Notary code of ethics". Based on Article 1 letter $b$ of the Indonesian Notary Association (INI) Code of Ethics for Notaries, Code of Ethics for Notaries and hereinafter referred to as Code of Ethics are all moral principles determined by the Association of the Indonesian Notary Public which hereinafter will be referred to as "the Association" based on the decision of the Congress of the Association and/or which are determined by and regulated in the laws governing this and those that apply and must be obeyed by each and all members of the Association and all people who carry out their duties as Notaries, including Notary Temporary Officers, Substitute Notaries and Special Substitute Notaries. According to Article 1 number (5) of the Law on the Position of Notary Public, states that a Notary Public Organization is a professional organization for the position of a Notary which is formed by an association with legal status. The notary with his professional organization describes the professional ethics into the Notary Code of Ethics.

This Code of Ethics was prepared and designed by the Indonesian Notary Association (INI) which based on the Code of Ethics for Notaries Article 1 letter a means that the Indonesian Notary Association, abbreviated as INI, is an association/organization for Notaries, established since 1 July 1908, recognized as a legal entity (rechtpersoon) based on Gouvernements Bes/uit (Government Decree) dated 5 September 1908 Number 9, is the only unifying forum for all and everyone who holds and carries out their duties as a general official in Indonesia, as it has been recognized and received endorsement from the Government based on the Decree of the Minister of Justice of the Republic of Indonesia on January 23, 1995 Number C2- 1022.HT.01.06. 1995 and has been announced in the State Gazette of the Republic of Indonesia dated 7 April 1995 Number 28 Supplement Number 1/P-1995, therefore as and is a Notary Organization as referred to in Act No 30 of 2004 concerning the Position of Notary which was promulgated in the State Gazette of the Republic of Indonesia of 2004 Number 117. 
A code of ethics is guidance, guidance, moral guidelines or morality for a particular profession or a list of obligations in carrying out a profession that is compiled by members of the profession itself and binds them in practicing it. Thus, the Notary Code of Ethics is the guidance, guidance, moral guidance or morality of Notaries either as individuals or public officials appointed by the government in order to provide services to the general public, especially in the field of deeds making. as referred to in Act No 30 of 2004 concerning the Position of Notary which is promulgated in the State Gazette of the Republic of Indonesia of 2004 Number 117. A code of ethics is guidance, guidance, moral or moral guidelines for a particular profession or is a list of obligations in carrying out a profession that is composed by members of the profession itself and binding them in their practice. Thus, the Notary Code of Ethics is the guidance, guidance, moral guidance or morality of Notaries either as individuals or public officials appointed by the government in order to provide services to the general public, especially in the field of deeds making. Moral guidelines for a particular profession or a list of obligations in carrying out a profession that is compiled by members of the profession itself and binds them in practicing it.

The Notary Code of Ethics is the guidance, guidance, moral guidance or morality of Notaries either as individuals or public officials appointed by the government in order to provide services to the general public, especially in the field of deeds making. Moral or moral guidelines for a particular profession or a list of obligations in carrying out a profession that is compiled by members of the profession itself and binds them in practicing it. Thus, the Notary Code of Ethics is the guidance, guidance, moral guidance or morality of Notaries either as individuals or public officials appointed by the government in order to provide services to the general public, especially in the field of deeds making.

\subsection{Notary Professional Professionalism}

In carrying out his profession, a notary must act in accordance with the notary's professional ethics. Because in carrying out his duties, his position is not solely for personal interests, but for the benefit of the community.

In this case, the notary ethics in question is a code of ethics that is intended to carry out a profession so that it truly reflects professional work, morals, with motivation and tolerance of intellectual skills with rational arguments and critical. The professional meaning here is an understanding that creates certain activities in society armed with high expertise and based on a calling, as well as a pledge to accept the call, to with a spirit of devotion always ready to provide help to others who are in trouble in the middle of life. Thus a profession should never be confused with ordinary work aimed at earning a living and/or seeking worldly wealth. ${ }^{23}$

The elements of professionalism are:

a. A job that requires expertise; ${ }^{23}$ Wignjosoebroto, Soetandyo. (2001). Profesi profesionalisme dan Etika Profesi. PP INI: Media
Notariat, p. 32. 
eISSN : 2581-2114, pISSN: 2406-9426

b. For that it is necessary to get special training;

c. Get income from it.

It can be stated regarding the limitation of professional criteria which include:

a. Knowledge;

b. Skills or finesse;

c. Serve the interests of the people;

d. Not prioritizing financial interests;

e. The existence of a professional organization or association;

f. Public recognition; and

g. Code of Ethics

\section{CLOSING}

Notary is a position of trust, in carrying out his position as a public official, it must be in accordance with the corridors of duties and responsibilities as stated in the Law on Notary Position and the Notary's Code of Ethics. A Notary is obliged to act honestly, thoroughly and impartially. Honesty is important because if a notary acts dishonestly, there will be many events that will harm the public. Not only that, dishonesty will reduce the level of public trust. Violations committed by a Notary will have an impact on the deed he has made, the deed can have the power of proof under hand or be null and void. In connection with the Decision of the Notary Central Board of Investigators Number: 14/B/Mi.PPN/2009 where the Notary violates Article 264 jo. Article 263 of the Criminal Code, Article 378 of the Criminal Code, Article 1338 paragraph (3) of the Civil Code, Article 16 paragraph (1) of Law on Notary Position and Article 3 of the Code of Ethics for Notaries, according to Article 1320 The Civil Code, the Agreement Deed is null and void. Sanctions aimed at the Notary as an awareness that the Notary in carrying out his/her duties has violated the provisions regarding the implementation of the duties of the Notary as stated in the Notary Office Law, and to restore the Notary's actions in carrying out his/her duties in an orderly manner in accordance with the Position Law.

\section{References}

Journals:

Deen, Thaufiq., Ong Argo Victoria \& Sumain. (2018). Public Notary Services In Malaysia. JURNAL AKTA: Vol. 5, No. 4, 1017-1026. Retrieved from http://jurnal.unissula.ac.id/index.php/akta/article/view/4135

Ferdiyanti, M. Indah Verena., Purnawan, Amin., \& Soegiyanto. (2019). Setting the Effectiveness of Law Position and Code Notary to the Quality of Performance. 
eISSN : 2581-2114, pISSN: 2406-9426

JURNAL AKTA: Vol. 6, No. 4, 797-804. Retrieved from http://jurnal.unissula.ac.id/index.php/akta/article/view/7887

Widyawati, \& Handoko, Widhi. (2018). The Notary Role/PPAT in Improving Legal Awareness Society to Perform Registration Rights to Land Based on Government Regulation No. 24 of 1997 on Land Registration. JURNAL AKTA: Vol. 5, No. 4, 975-980. Retrieved from http://jurnal.unissula.ac.id/index.php/akta/article/view/4127

Books:

Adjie, Habib. (2009). Sekilas Dunia Notaris \& PPAT Indonesia (Kumpulan Tulisan), Bandung: CV. Badar Maju

Anshori, Abdul Ghofur. (2010). Lembaga Kenotariatan Indonesia Persefektif Hukum dan Etika. Yogyakarta: UII Press

Darmodiharjo, Darji \& Shidarta. (2004). Pokok-pokok Filsafat Hukum, Apa dan Bagaimana Filsafat Hukum Indonesia. Jakarta: PT Gramedia Pustaka Utama

Kie, Tan Thong, (2007). Studi Notariat beberapa Mata Pelajaran dan Serba Serbi Praktek Notari. Jakarta: Pt. Ichtiar Baru Van Hoeve

Kie, Tan Thong. (2000). Buku 1 Studi Notariat dan Serba Serbi Praktek Notaris, Jakarta: PT. Ichtiar Baru Van Hoeve

Manan, Bagir. (2004). Hukum Positif Indonesia. Yogyakarta: UII Press

Notodisoerjo, R. Soegondo. (1993). Hukum Notariat di Indonesia Suatu Penjelasan. Jakarta: PT. Raja Grafindo Persada

R. Soeroso. (2016). Pengantar IImu Hukum. Print. 17. Jakarta: Sinar Grafika

Sulihandari, Hartanti \& Nisya Rafiani. (2013). Prinsip-Prinsip Dasar Profesi Notaris. Jakarta: Dunia Cerdas

Supriadi. (2008). Etika Dan Tanggung Jawab Profesi Hukum Di Indonesia. Jakarta: Sinar Grafika

Thaw, Deborah M. (2000). The Notary Public and its Impact in $21^{\text {st }}$ Century, A Persentation at the NACO/NACRC Annual Conference

Tobing, G.H.S. Lumban. (1999). Peraturan Jabatan Notaris. Jakarta: Erlangga

Wignjosoebroto, Soetandyo. (2001). Profesi profesionalisme dan Etika Profesi. PP INI: Media Notariat

Internet:

http://www.indonesianotarycommunity.com/k Character-yuridis-jabat-notaris/, accessed on January 5, 2020 12:56

http://www.jimlyschool.com/read/anal/384/notaris-openbare-amtbtenaren-syafransofyan/, accessed on January 5, 2020 14:21. 